\title{
Study Abroad and Willingness to Communicate: A Case Study at Junior High School
}

\section{Adrian Leis}

\author{
Miyagi University of Education
}

The goal of this paper is to gain a deeper understanding of whether a short study abroad program is effective in increasing its participants' willingness to communicate in a second language. Using a questionnaire designed by Yashima (2002), a pre-post design study was used to examine a sample of 80 Japanese junior high school students who participated in a ten-day study abroad program to Sydney, Australia. The results indicate that although there were no statistically significant differences seen in the second language learning motivation of the students participating in the study abroad program, there were salient decreases observed in the anxiety students felt towards speaking English. Furthermore, as clear differences were seen in international posture, joining the study abroad program also meant that students felt more a part of the global community. Based on these results, the author concludes that traveling abroad for the purposes of study is indeed effective for adolescent learners of English, helping them feel more comfortable using the language as a tool for communication.

本論の目的は、短期海外研修参加者の第2言語におけるWillingness to Communicate (WTC) の向上に及ぼす効果について、より深い知見を獲得 することである。八島 (2002) によって作成されたアンケートを用い、シド 二一・オーストラリアでの10日間の海外研修に参加した80人の日本人中学 生のサンプルを事前事後調査方式で研究を行つた。結果からわかったこ とは、統計的にみると海外研修に参加した生徒の第2言語における学習 意欲には有意差が見られなかったが、生徒が英語を話すことに対して抱い ていた不安の軽減が顕著に見られたということである。さらに、国際的な 姿勢に明らかな差異が見られ、海外研修への参加は、生徒が国際社会の 一員としての認識を強めるものとなっていた。これらの結果により、筆者 は、学習を目的とする海外研修は英語を学ぶ生徒には非常に効果があり 海外研修によって生徒たちはより安心感を持って言語をコミュニケーショ ンツールとして用いることができるようになったとの結論に達した。

$\mathrm{t}$ is a common belief of many foreign language students, their parents and even their teachers, that simply participating in a study abroad (SA) program will open the floodgates of language, making those who participate confident and fluent in the tongue of the country that they visit. Those who travel abroad are provided with opportunities to experience the culture and language of a foreign country in a way that cannot be felt in regular language classes or even in immersion programs. There is no doubt that with the increasing awareness of the importance of globalization in modern society, the realization of being a member of the international community is vital for young students learning English as a foreign language (EFL). This is especially true for Japan, an island nation with few chances for young learners to experience English on a daily basis.

However, despite the obvious importance of studying abroad, the Ministry of Education, Culture, Sports, Science and Technology (MEXT) announced that in recent years there has been a decrease in the number of Japanese students studying abroad (2013). The number of Japanese citizens studying overseas peaked at 82,945 in 2004 and has since seen a steady decline to 58,060 in 2010 . On the other hand, the number of schools who take their students abroad on their school trip, commonly known as the shuugakuryokou in Japanese, has gradually increased since 2004 to a total of 827 high schools and 110 junior high schools in 2011 (Educational Tour Institute, 2012).

The effect of studying abroad has received much interest in the field of second language acquisition (SLA) with various results. Some researchers (e.g., Yashima, Zenuk-Nishide, \& Shimizu, 2004; Yashima \& Zenuk-Nishide, 2008) suggest that studying abroad brings about positive linguistic outcomes with students being more willing to communicate in English upon returning to their home country. Freed (1990) and Sasaki (2011) reported that studying abroad resulted in an increase in the motivation of participants, but only after a period of at least one university semester (i.e., three months). In recent studies of the effects of an SA program on the motivation of junior and senior high school students by Leis (2013, 2014a), it was reported that an SA program much shorter than the minimum period recommended by Freed (1990) and Sasaki (2011) can in fact be beneficial for participants, but only with teachers' guidance through language classes and assessment in the months after returning from abroad. In my pervious studies (Leis, 2013, 2014a, 2014b), motivation was measured using Dörnyei's (2005) Second Language (L2) Motivational Self 
System. A weakness with measuring the motivation of students in this way was the age of students. When creating ideal and ought images, the core of Dörnyei's L2 Motivational Self System, teenagers may be influenced to fit in with their peers' images (Oyserman, Bybee, \& Terry, 2006; Pizzolato, 2006). Thus, in the current research, I focus on motivation from a different perspective: the willingness to communicate (WTC) in a L2, and whether studying abroad, even for a short time, increases participants' desire to speak in English.

The model of WTC, introduced by MacIntyre, Clément, Dörnyei, and Noels (1998), gives a representation of using a $\mathrm{L} 2$ to realize a communicative goal, rather than placing importance on being competent in communicating in the L2. The model of WTC in a L2 has been the basis of much research in SLA (e.g., Yashima, 2002; Yashima, Zenuk-Nishide, \& Shimizu, 2004; Kang, 2005). Yashima (2002) included a new dimension in her L2 communication model, marking International Posture, a notion that reflects students' interest in international news and an open mind to foreign attitudes and culture, as an important aspect in L2 learners' communication behavior. Yashima et al. (2004) explain that this is especially relevant for Japanese EFL learners because of the importance put upon English as a subject required for entrance examinations to higher schooling rather than principally for communication. Yashima et al. (2004) used Yashima's (2002) communication model to see the effects of an SA experience on Japanese high school students, and whether WTC predicts the frequency and amount of communication the participants undertake. The results showed that there was a connection between higher perceived communicative competence before traveling abroad and reflected the amount of communication by participants. In this study, I look at how an SA experience affected the components of Yashima's (2002) model of communication, and whether this was effective in strengthening the $\mathrm{L} 2$ WTC of participants.

\section{This Study}

The aim of the present study is to answer the following research questions:

1. Is a short SA program effective in increasing the motivation of students to study English?

2. Is a short SA program effective in decreasing the amount of anxiety students feel in their ability to communicate in English?

3. Does a short SA program have a positive effect on the international posture of participants?
These three categories, in addition to $\mathrm{L} 2$ proficiency, are the factors that make up the L2 Communication Model that Yashima (2002) designates to be an accurate indicator of students' WTC in an L2.

\section{Method}

\section{Participants}

A sample of 80 third-year students attending a junior high school at a combined junior-senior high school in northeast Japan participated in this study. The data from five students were excluded from the analysis, as they were either absent when one of the questionnaires was conducted, or did not complete the questionnaires correctly. Of the 75 students whose data were used for this research, 52 were female and 23 were male. Although no proficiency test was conducted in this study, as English education is compulsory from the first year of junior high school, the students had had three years of official English education, suggesting they had low-intermediate English proficiency. From the sample of 75 students, 12 (16\%) indicated they had had experience traveling abroad with three of those (4\% of the entire sample for analysis) having visited an English speaking country.

\section{Materials}

A questionnaire (see Yashima, 2009) was used for the purposes of this study. The questionnaire included a total of 88 items consisting of statements related to students' motivational intensity (e.g., I feel that I study more than my classmates), students' desire to learn English (e.g., If possible, I would like the amount of time we study English at school to increase), intercultural friendship orientation (e.g., I want to make friends with people from foreign countries.), ethnocentrism (e.g., I find it difficult to cooperate with people who do not share the same beliefs as I do), interest in foreign affairs (e.g., I often read about and watch news related to foreign affairs), intergroup approach avoidance tendencies (e.g., If there were an exchange student at my school, I would try to initiate conversations with him/her), and interest in international activities (e.g., In the future, I would like to work in an international organization such as the United Nations). Participants were asked to use Likert scales from one (That is completely untrue) to seven (That is completely true) to indicate the degree to which each statement described their feelings. In addition to these categories, participants were asked to show on a percentage scale from zero to 100 their communication anxiety when speaking English in certain situations (e.g., Holding a conversation with someone you do not know), communication compe- 
tence when speaking English in certain situations (e.g., Giving a speech in front of a group of people you know) and willingness to communicate in English in certain situations (e.g., Expressing your opinion during a meeting). The questionnaire was conducted in Japanese.

\section{Procedure}

Questionnaires were conducted in a pre-post design, with the first being completed one week before departure at the end of a three-hour intensive English conversation class. The students then participated in a ten-day trip to Sydney, Australia. As this trip was part of their school curriculum, it was compulsory for students to join this program. While in Australia, students stayed with local families and participated in English conversation classes and cultural activities, including a cultural exchange with Australian students of a similar age. The second questionnaire was conducted one week after students returned from abroad, at the end of a two-hour lecture, in which students discussed their SA experiences. The results were entered into an Excel file and then analyzed using SPSS Version 20 to find salient differences in students' willingness to communicate in an L2 before and after traveling abroad.

\section{Results and Discussion}

\section{L2 Learning Motivation}

The first research question in this study looks at the effects a short study abroad program has on participants' motivation to study English. A Cronbach's Reliability Analysis was conducted with the results indicating the data in the categories of Motivational Intensity (MI) $(\alpha=.923)$ and Desire to Learn English (DLE) $(\alpha=.867)$ were suitable for analysis. Data were analyzed by a one-way analysis of variance (ANOVA), 95\% Confidence Interval $(95 \% \mathrm{Cl})$ and Eta Partial Square $\left(\eta^{2}\right)$ analyses. Table 1 displays descriptive statistics for the categories of L2 Learning Motivation in Yashima's (2002) model of WTC, before and after the students had participated in their SA program. Neither MI, $F(1,148)=.368, p=.545, \eta^{2}=$ .002 , nor DLE, $F(1,148)=.021, p=.885, \eta^{2}=.000$, showed any significant difference after returning from abroad, suggesting that traveling abroad for a short time has no impact on participants' motivation to learn a L2.

Showing similar results to previous research, (Freed, 1990; Sasaki, 2011; Leis, 2013, 2014a), it seems that a ten-day SA program is not long enough to see any salient increase in the L2 learning motivation of its participants. The reason for this could have been that the students were traveling as a group, not as individuals. The students in this study traveled as a group of 80 . Therefore, the number of situations where they had to use English without relying on their classmates to help them may have been limited. Because of this, students may have had few experiences where they could not make themselves understood in English, even if they only used single words without any sentence structure. As a result, students may have been satisfied with their English proficiency at the time, thus their motivation to learn English more did not increase significantly. Furthermore, the size of the group may have meant that students used Japanese with their peers more than speaking English with native speakers. This reflects the findings of Trentment (2013), who suggested that students studying in a group abroad tend to use their mother tongue more than the language of the country they are visiting. Conducting longitudinal studies, looking at the L2 learning motivational changes of students who participate in individual SA programs and for longer periods, may bring different results to the current findings.

\section{L2 Communication Confidence}

The second research question in the current study looks at changes in participants' L2 communication confidence after returning from abroad. It was predicted by the author that after experiencing a situation in which they were able to successfully

Table 1. Descriptive Statistics for L2 Learning Motivation Categories in the Current Study

\begin{tabular}{lcccccc}
\hline Category & Time & $M$ & $S D$ & Skewness & Kurtosis & $95 \% \mathrm{Cl}$ \\
\hline MI & Before & 3.96 & 1.27 & 0.127 & -0.331 & {$[3.67,4.26]$} \\
& After & 4.10 & 1.38 & -0.239 & -0.842 & {$[3.78,4.41]$} \\
\multirow{2}{*}{ DLE } & Before & 4.34 & 1.15 & -0.106 & 0.231 & {$[4.08,4.61]$} \\
& After & 4.37 & 1.27 & -0.291 & -0.453 & {$[4.08,4.66]$} \\
\hline
\end{tabular}

Note. $N=75$; MI: Motivational Intensity; DLE: Desire to Learn English; Max. = 7; Min. = 1 . 
communicate in English in an authentic all-English environment without having to be concerned with the grammatical accuracy of their utterances, the communication anxiety (CA) of students would decrease significantly, while an increase in perceived communicative competence in English (PC) would also be observed. This hypothesis was based on similar previous research by the author (Leis, 2014a) in which students remarked, "Through this experience, I have learned the enjoyment of communicating with people from other countries," suggesting that the experience in an all-English environment was enjoyable and gave students confidence in being able to converse in English.

A Cronbach's Reliability Analysis was conducted with the results indicating the data was suitable to be analyzed in both categories of CA $(\alpha=.901)$ and PC $(\alpha=.915)$. Data were analyzed to find significant increases or decreases comparing before and after the SA program by a one-way ANOVA, $95 \% \mathrm{Cl}$, and Eta Partial Square $\left(\eta^{2}\right)$ analyses. Table 2 displays descriptive statistics for the categories of L2 Communication Confidence in Yashima's (2002) model of WTC, prior to and after the students had participated in their SA program. As had been hypothesized before the study, results showed a statistically significant decrease in CA, $F(1,148)=6.11, p=.015, \eta^{2}=.040$ with medium effect size. However, the experience did not show any significant increase in how students perceived their communication competence in English, $F$ (1, 148) $=1.73, p=.191, \eta^{2}=.012$.

In their English education at school, where grammatical accuracy is often focused upon, students may feel some anxiety towards speaking due to the fear of making mistakes and being embarrassed in front of their peers. Covington $(1992,1998)$ suggests that school is the place where students' ability is judged by teachers and their peers, and where they feel the most pressure to perform well. This is supported by the relatively high anxiety (i.e., 63.59) shown by students in the sample before traveling abroad. Few participants had had experience visit- ing an English speaking country, therefore it can be concluded that the main reasons for the anxiety felt by students were expectations of their teachers and peers at school. This supports the findings of Kondo and Yang (2003), who claimed anxiety in an EFL classroom could be related to three primary components: low proficiency, speaking activities, and the fear of receiving negative feedback from their peers.

However, participating in the SA program helped ease some of that anxiety. Having opportunities to 'try out' their English with native speakers in an English-only environment may have resulted in students feeling that English does not necessarily always need to be spoken with perfect grammatical accuracy, and even if they do make some mistakes, they are still able to convey their message. On the other hand, students may have also realized that they lacked the vocabulary bank and listening skills to be competent in communicating successfully in English. This is strengthened by previous research (Leis, 2014a), in which I concluded that an SA program was effective in increasing participants' awareness of the importance of expanding their vocabulary bank for successful communication.

\section{International Posture}

Finally, the third research question in the current study looks at changes in participants' International Posture, and whether this short time abroad had an impact on their feelings as members of the global community. The author predicted that, based on the age of the participants along with the experience of staying with Australian families and interacting with Australian school children of a similar age, although Intercultural Friendship Orientation (IFO) and Intergroup Approach Avoidance Tendency (AAT) would see a significant increase after returning to Japan, their experiences in Australia would not be sufficient to make any significant increases or decreases in the students' Interest in International Activities (IVA), or Interest in Foreign Affairs (IFA). Once again, a Cronbach's Reliability

Table 2. Descriptive Statistics for Communication Confidence in the Current Study

\begin{tabular}{lcccccc}
\hline Category & Time & $M$ & $S D$ & Skewness & Kurtosis & $95 \% \mathrm{Cl}$ \\
\hline CA & Before & 63.59 & 19.30 & -0.644 & 0.699 & {$[59.15,68.03]$} \\
& After & $55.57^{*}$ & 20.45 & -0.170 & -0.640 & {$[50.86,60.27]$} \\
PC & Before & 35.31 & 16.15 & -0.102 & -0.325 & {$[31.60,39.03]$} \\
& After & 38.93 & 17.53 & 0.027 & -0.138 & {$[34.40,42.97]$} \\
\hline
\end{tabular}

Note. $N=75$; CA: Communication Anxiety in L2; PC: Perceived Communication Competence in English; Max. = 100; Min. $=0 ; * p=<.05$. 
Analysis was conducted with the results indicating the data in the categories of IFO $(\alpha=.878)$, AAT $(\alpha$ $=.884)$ and IVA $(\alpha=.759)$ to be suitable for analysis. However, the reliability of the fourth measure, IFA $(\alpha=.242)$, was deemed to be too low and therefore will not be analyzed further in this paper.

The three variables of IFO, AAT and IVA were analyzed to find significant increases or decreases comparing before and after the SA program using a oneway ANOVA, $95 \% \mathrm{Cl}$ and Eta Partial Square $\left(\eta^{2}\right)$ effect size analyses. Table 3 displays descriptive statistics for the categories of International Posture in Yashima's (2002) model of WTC, prior to and after the students had participated in their SA program. As had been hypothesized before the study, results showed a statistically significant increase in $\operatorname{IFO}, F(1,148)=$ $8.79, p=.004, \eta^{2}=.056$ with medium effect size and AAT, $F(1,148)=4.57, p=.034, \eta^{2}=.030$ with weak to medium effect size. Furthermore, the experience did not seem long enough, or give participants enough opportunities to show any salient development in students' interest in international or vocational activities, with no significant increase being seen in this variable, $F(1,148)=1.12, p=.292, \eta^{2}=.008$.

As expected, due to the type of communication experienced by students on their SA program and reflecting the ease on communication anxiety as discussed in the previous section, students felt more comfortable in making friends and, to a lesser degree, felt more confident to converse in an English-speaking environment. Communication with host families and Australian students of a similar age did not result in a significant increase in subjects' IVA. This could be due to the insufficient English proficiency level and lack of vocabulary of the students in this sample to participate in conversations related to IVA. Subjects who have a level of English proficiency advanced enough to understand and participate in conversations or read news relat- ed to international issues may show more significant increases in this area.

\section{Conclusion}

This paper has discussed the effects participating in a short SA program has on the WTC in a L2 of adolescent EFL learners. In similar results to previous research, ten days seems too short to have any statistically significant effect on the L2 learning motivation of participants. However, even a short trip such as the one described in this paper has clear advantages for those who join it. First, the experience of getting their message across in English seems to help reduce the amount of anxiety they feel with the language. The data suggest that this anxiety may be due to a focus on grammatical accuracy in their regular EFL classes at school. As the participants in this study had had very little or no experience living in an all-English speaking environment, the author has concluded that the anxiety students felt was due to pressure related to classroom tests and academic achievement. The Japanese English education system has been described by several authors (e.g., Eckstein \& Noah, 1989; Amano, 1990; Gorsuch, 2000; Yashima, Zenuk-Nishide, \& Shimizu, 2004; Nishino, 2006) as one that focuses on improving students' grammatical accuracy and ability to get through college and university entrance exams, an approach in Japan that is believed to be "an essential element of instructional guidance" (Cohen \& Spillane, 1992, p. 15). Hashimoto (2002) argued that anxiety resulted in students having negative feelings towards their perceived language competence, and in turn their WTC in the L2 also declined. With a significant reduction in the anxiety felt by students in this study, it can be concluded that an SA program is effective is opening opportunities for students to feel more confident in speaking English

Table 3. Descriptive Statistics for International Posture in the Current Study

\begin{tabular}{llllllc}
\hline Category & Time & $M$ & $S D$ & Skewness & Kurtosis & $95 \%$ CI \\
\hline IFO & Before & 4.43 & 1.33 & -0.079 & -0.134 & {$[4.12,4.73]$} \\
& After & $5.07 * *$ & 1.32 & -0.675 & 0.300 & {$[4.76,5.37]$} \\
\multirow{2}{*}{ AAT } & Before & 4.15 & 1.24 & -0.166 & 0.138 & {$[3.87,4.44]$} \\
& After & $4.57 *$ & 1.16 & -0.325 & -0.158 & {$[4.31,4.84]$} \\
IVA & Before & 4.22 & 1.25 & 0.033 & -0.575 & {$[3.93,4.51]$} \\
& After & 4.44 & 1.22 & -0.078 & -0.557 & {$[4.16,4.72]$} \\
\hline
\end{tabular}

Note. $N=75$; IFO: Intercultural Friendship Orientation; AAT: Intergroup Approach Avoidance Tendency; IVA: Interest in International/Vocation Activities; Max. $=7$; Min. $=1 ; * p=<.05 ; * * p=<.01$. 
without having to worry about the grammatical accuracy of their utterances.

Second, reflecting on the decreased anxiety felt by students, they showed significantly more confidence as members of the international community. Although there was no significant increase in interest in international activities by the participants, perhaps due to their age or English proficiency, there was a salient increase in the desire students had to communicate with native speakers of English. Further research through a third questionnaire, conducted about six months after students have returned from abroad, may provide an insight as to whether this enthusiasm to communicate with native speakers of English has an effect on the quality and quantity of students' study time, and whether these effects are lasting.

The lack of a third questionnaire to discover whether the effects of studying abroad are permanent even after returning to Japan is, admittedly, a weakness of the current research. In previous studies, I (Leis 2013, 2014b) argued that when teachers were able to incorporate the experiences students had abroad into their regular classes and assessment, the effects of the SA program strengthened further two months after returning to Japan. Furthermore, without a control group, in which the researcher could have conducted the questionnaires with students who did not study abroad, the current paper lacks concrete evidence that the changes in students' L2 anxiety and international posture were in fact purely due to an experience in an all-English environment, not some other factor. In future projects, the researcher will include a control group to strengthen the argument that studying abroad, even for less than two weeks, is beneficial for the participants.

Despite these weaknesses, this paper has given statistical evidence that studying abroad is a valuable experience for those who participate, regardless of its length. Such an experience brings participants to feel more relaxed in conversing in English, as well as increase the willingness they feel to join conversations with native speakers of English. With further research to show the benefits of an SA program, it is hoped more young Japanese EFL students will take the opportunity to travel to environments that help make them feel more comfortable and confident communicating in their chosen language.

\section{Acknowledgements}

This paper was supported in part by Grant-in-Aid for Young Scientists B (N.o. 25770200). Much appreciation goes to Mineyoshi Aoyama for his support throughout this study. The author wishes to thank Tomoko Yashima for granting permission to use the questionnaire for this study and comments on a previous version of this paper. I would also like to show my gratitude to the TLT Editor and anonymous reviewers for their comments and suggestions. All remaining errors are the responsibility of the author.

\section{References}

Amano, I. (1990). Education and examination in modern Japan. Tokyo: University of Tokyo Press.

Cohen, D. K., \& Spillane, J. P. (1992). Policy and practice: The relations between governance and instruction. Review of Research in Education, 18, 3-49.

Covington, M. (1992). Making the grade: A self-worth perspective on motivation and school reform. Cambridge: Cambridge University Press.

Covington, M. (1998). The will to learn. New York: Cambridge University Press.

Dörnyei, Z. (2005). The psychology of the language learner: Individual differences in second language acquisition. Mahwah, NJ: Lawrence Erlbaum.

Eckstein, M., \& Noah, H. (1989). Forms and functions of secondary school leaving examinations. Comparative Education Review, 33, 295-316.

Educational Tour Institute. (2012). Heisei 23 nendo (2011) zenkoku koushiritsu koutougakkou kaigaishuugakuryokou kaigaikenshuu (shugakuryokougai) jisshijoukyouchousa houkoku [A report on the current state of school trips and study trips abroad in Japanese private and public high schools in 2011]. Retrieved from <http://shugakuryoko.com/chosa/kaigai/2011-01-hyoushi.pdf>

Freed, B. F. (1990). Language learning in a study abroad context: The effects of interactive and non-interactive out-of-class contact on grammatical achievements and oral proficiency. In J. Atlatis (Ed.), Linguistics language teaching and language acquisition: The independence of theory, practice and research (pp. 459-477). Georgetown University Round Table on Languages and Linguistics. Washington DC: Georgetown University Press.

Gorsuch, G. (2000). EFL education policies and education cultures: Influences on teachers' approval of communicative activities. TESOL Quarterly, 34(4), 675-710.

Hashimoto, Y. (2002). Motivation and willingness to communicate as predictors of L2 use: The Japanese ESL context. Second Language Studies, 20, 29-70.

Kang, S. (2005). Dynamic emergence of situational willingness to communicate in a second language. System, 33, 277-292.

Kondo, S., \& Yang, Y. L. (2003). The English language classroom anxiety scale: Test construction, reliability, and validity. JALT Journal, 25, 593-598. 
Leis, A. (2013). Effects of studying abroad on the motivation and metacognition of high school students. Papers of Foreign Language and Studies at Miyagi University of Education, 7, 31-58.

Leis, A. (2014a). The effects of a study abroad experience on the L2 Motivational Self and metacognitive skills: A study of a junior high school trip abroad. Bulletin of Miyagi University of Education, 48, 199-209.

Leis, A. (2014b). How teaching styles affect the motivation of students returning from short-term experiences abroad. Bulletin of Miyagi University of Education Research Center for Education in International Understanding, 9, 30-37.

MacIntyre, P., Clément, R., Dörnyei, Z. \& Noels, K. (1998). Conceptualizing willingness to communicate in a L2: A situated model of L2 confidence and affiliation. Modern Language Journal, 82, 545-562.

MEXT. (2013). Nihonjin no kaigairyuugaku joukyou [The current state of Japanese citizens studying abroad]. Retrieved from <http://www.mext. go.jp/b_menu/houdou/25/02/__icsFiles/afieldfile/2013/02/08/1330698_01.pdf>

Nishino, T. (2008). Japanese secondary school teachers' beliefs and practices regarding communicative language teaching: An exploratory survey. JALT Journal, 30 (1), 27-50.

Oyserman, D., Bybee, D., \& Terry, K. (2006). Possible selves and academic outcomes: How and when possible selves impel action. Journal of Personality and Social Psychology, 91(1), 188-204.

Pizzolato, J. (2006). Achieving college student possible selves: Navigating the space between commitment and achievement of long-term identity goals. Cultural Diversity and Ethnic Minority Psychology, 12(1), 57-69.

Sasaki, M. (2011). Effects of various lengths of studyabroad experience on Japanese EFL students' L2 writing ability and motivation: A longitudinal study. TESOL Quarterly, 45(1), 81-105.
Trentman, E. (2013). Arabic and English during study abroad in Cairo, Egypt: Issues of access and use. The Modern Language Journal, 97(2), 457-473.

Yashima, T. (2002). Willingness to communicate in a second language: The Japanese EFL context. The Modern Language Journal, 86(1), 54-66.

Yashima, T. (2009). International posture and the ideal L2 self in the Japanese EFL context. In Z. Dörnyei \& E. Ushioda (Eds.), Motivation, language identity and the L2 self. Clevedon, UK: Multilingual Matters. 144-163.

Yashima, T., \& Zenuk-Nishide, L. (2008). The impact of learning contexts on proficiency, attitudes, and L2 communication: Creating an imagined international community. System, 36, 566-585.

Yashima, T., Zenuk-Nishide, L. \& Shimizu, K. (2004). The influences of attitudes and affect on willingness to communicate and second language communication. Language Learning, 54(1), 119-152.

Adrian Leis is an associate professor in the English Education Department at Miyagi University of Education. His research interests center on L2 learning motivation and CALL/MALL. He conducts flipped classrooms through his YouTube channel and posts thoughts about language learning and motivation on

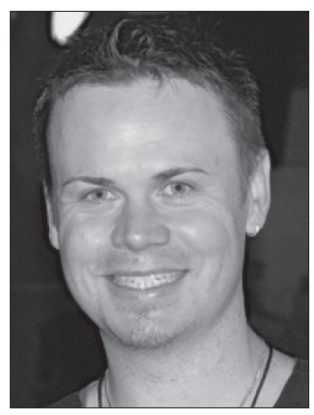
Twitter. He has more than 15 years experience teaching English in Japan. He can be contacted at <adrian@staff.miyakyo-u.ac.jp>.

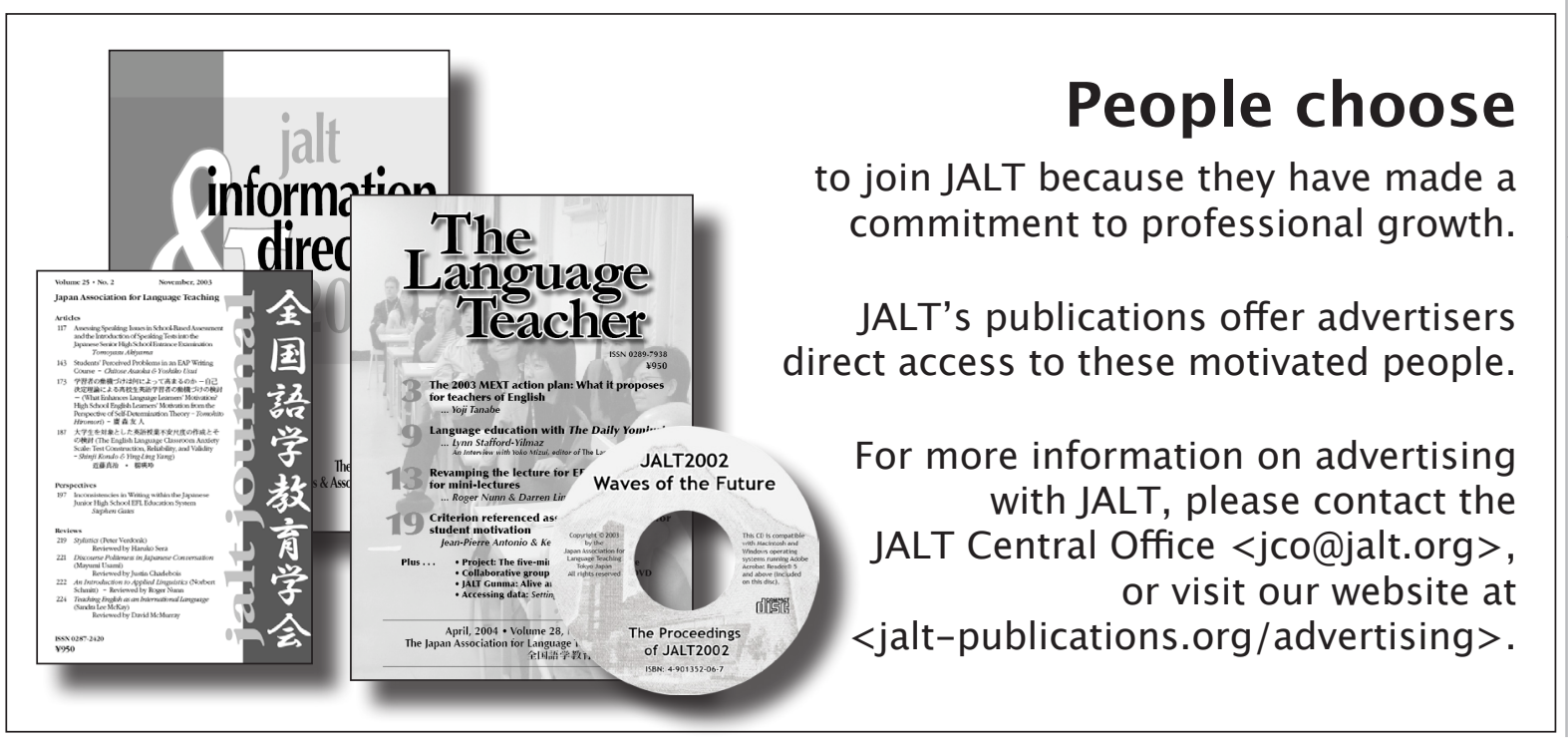

